\title{
Codend selectivity in a commercial Danish anchor seine
}

\author{
Noack, Thomas; Frandsen, Rikke; Krag, Ludvig Ahm; Mieske, Bernd; Madsen, Niels
}

Published in:

Fisheries Research

Link to article, DOI:

10.1016/j.fishres.2016.10.006

Publication date:

2017

Document Version

Peer reviewed version

Link back to DTU Orbit

Citation (APA):

Noack, T., Frandsen, R., Krag, L. A., Mieske, B., \& Madsen, N. (2017). Codend selectivity in a commercial Danish anchor seine. Fisheries Research, 186, 283-291. https://doi.org/10.1016/j.fishres.2016.10.006

\section{General rights}

Copyright and moral rights for the publications made accessible in the public portal are retained by the authors and/or other copyright owners and it is a condition of accessing publications that users recognise and abide by the legal requirements associated with these rights.

- Users may download and print one copy of any publication from the public portal for the purpose of private study or research.

- You may not further distribute the material or use it for any profit-making activity or commercial gain

- You may freely distribute the URL identifying the publication in the public portal

If you believe that this document breaches copyright please contact us providing details, and we will remove access to the work immediately and investigate your claim. 


\section{Codend selectivity in a commercial Danish}

\section{2 anchor seine}

3 Thomas Noack ${ }^{1 *}$, Rikke P. Frandsen ${ }^{1}$, Ludvig A. Krag ${ }^{1}$, Bernd Mieske ${ }^{2}$, Niels

4 Madsen $^{3}$

${ }^{1}$ Technical University of Denmark, National Institute of Aquatic Resources, North Sea Science Park, PO Box 101,

6 DK-9850 Hirtshals, Denmark

$7 \quad{ }^{2}$ Thünen-Institute of Baltic Sea Fisheries, Alter Hafen Süd 2, 18069 Rostock, Germany

$8{ }^{3}$ Section of Biology and Environmental Science, Department of Chemistry and Bioscience, Aalborg University,

$9 \quad$ Fredrik Bajers Vej 7, 9220 Aalborg, Denmark.

$10 \quad{ }^{*}$ Corresponding author: tel: +45358832 51; email: thno@aqua.dtu.dk

\section{Abstract}

12 Danish seining (or anchor seining) is a fishing technique that is gaining increasing attention because it is 13 considered to be a fuel-efficient fishing method with low environmental impact. However, scientific 14 documentation of the selectivity characteristics of Danish seines is lacking, and the gear generally is 15 grouped with bottom trawls and Scottish seines in fisheries management legislation. In this study, we 16 developed a codend cover to estimate the selectivity of a standard commercial Danish seine codend for 17 four fish species. The data for the dominant species, dab (Limanda limanda) and plaice (Pleuronectes 18 platessa), was best described by models that combine two or three logistic models, which indicated that 19 more than one selection process was at work. Selectivity of cod (Gadus morhua) was best described by 20 a Richard curve and selectivity of red gurnard (Chelidonichthys lucernus) by a logistic curve. The 21 estimated selectivity curve of dab indicated, contrary to cod and plaice, low retention of individuals 22 below MLS. Confidence limits for larger length classes of cod and red gurnard were relatively wide. For 23 plaice, the estimated selection factor, which is the length with 50\% retention divided by mesh size, was 24 comparable to literature values from trawl studies. The average value for cod was similar for Danish and 25 Scottish seines, but lower for trawls. The results are discussed in the context of fisheries management with focus on the landing obligation of the new Common Fisheries Policy. 
27 Keywords: Demersal seining, Discard ban, Landing obligation, Multiple selection, Selectivity

28 modelling, Skagerrak

\section{1. Introduction}

Although a decline in the number of seiners in Denmark is evident (1990: 252; 2000: 118; 2015: 32; EuroStat, 2016), Danish seining is still an important fishing technique. In recent years, interest in Danish seining has increased because it is viewed as a fuel-efficient fishing method (Thrane, 2004) and because its environmental impacts are said to be less than those of other active demersal fishing gears such as beam trawls or bottom trawls (ICES, 2006, 2010; Suuronen et al., 2012; Eigaard et al., 2015). The main target species of Danish seiners in Skagerrak and the North Sea are flatfish, primarily plaice (Pleuronectes platessa), which has been within safe biological limits for the last three years (ICES, 2015). Nevertheless, there is a general lack of scientific documentation of the selectivity of Danish seines. The sparse existing data (e.g. ICES, 2010; Suuronen et al., 2012) are often based on assumptions or older studies, where other regulations existed, different gears or vessels were used or where data were not analysed following the standards described in Wileman et al. (1996).

A new Common Fisheries Policy that includes a landing obligation (discard ban) system was introduced in most European Union (EU) waters, including Skagerrak and the North Sea, by 1 January 2016 (EEC, 2011, 2012; Condie et al., 2014b; Condie et al., 2014a; Eliasen, 2014; Uhlmann et al., 2014; Sardà et al., 2015). The specific challenge for the industry, and the major difference from the earlier landing quota system is that the catch of all sizes of listed species is counted against the quota. A minimum conservation reference size (MCRS, generally equal to current minimum landing size, MLS) will be introduced for several commercial species and individuals below this size are prohibited from being sold for direct human consumption. Consequently, information about the selective properties of fishing gears is of great importance for the economy and fisheries management as selectivity parameters like L50 (length at which 50\% of the fish are retained) and SR (selection range; L75-L25, give an indication of which sizes of fish can be expected by the fishery. This information is important to estimate 
52 the probability that the fisheries will adhere the objectives of the landing obligation. Furthermore, if the 53 expectations of the landing obligation are too high (e.g. due to high bycatches of fish below MCRS), the 54 data may allow for recommendations to be made on how to adjust the fisheries to the new system.

By EU law, Danish seines belong to the same legislative category of fishing gears as Scottish seines and bottom trawls. All three gears follow the same technical regulations such as mesh size and 57 selective devices. Several older studies regarding selectivity of Scottish seines exist (Reeves et al., 1992; 58 Isaksen and Lokkeborg, 1993) but the overall state of knowledge is low. A recent theoretical study by 59 Herrmann et al. (2015) estimated the selectivity of Scottish seines on the basis of one of those earlier 60 studies using suitable statistical methods. Nevertheless, they concluded that further studies have to be 61 conducted using currently used demersal seines. The understanding of selectivity in bottom trawls is 62 much greater as the majority of selectivity studies for gears from this legislative category focused on 63 trawls (e.g. Reeves et al., 1992; Graham et al., 2004; Frandsen et al., 2010b; Madsen et al., 2012). Although the netting materials and codend constructions used in Danish seines, Scottish seines, and bottom trawls are similar, the gears have pronounced differences in construction and in the way they are operated. Bottom trawls use trawl doors to spread the net (von Brandt, 2005), and the towing speed

67 is relatively constant throughout the fishing process. Seiners do not use any doors or other spreading devices, and the speed at which the net is dragged is slower than that in trawling, but it continuously increases during the fishing process. Scottish seiners move forward during the retrieval process, whereas Danish seiners do not as they are anchored (von Brandt, 2005). With such pronounced differences in

71 towing speed and net geometry during the fishing process, it is likely that the selection processes differ 72 among the three types of gears.

Due to the lack of consistent forward motion in Danish seines, it is important to develop a cover

74 based on the principles of the conventional codend cover (Wileman et al., 1996) to study the selectivity 75 of this type of gear. Such a device must cope with the different stages of the fishing process and always 76 keep the cover a sufficient distance away from the codend to avoid a potential masking effect that can 77 occur when the cover comes in contact with the meshes of the codend (Madsen and Holst, 2002). 
The main objective of this study was to estimate the selectivity parameters for species caught

79 with Danish seines using the codend design currently used in the commercial fishery. These selectivity

80 parameters were compared to those of bottom trawls and Scottish seines, and the results should prove

81 useful in terms of technical regulations and management policies. The data will also be used to evaluate

82 the gear in terms of the landing obligation and to estimate the potential consequences for the Danish

83 seine and bottom trawl sector now, and in the future, should other species be added to the landing

84 obligation list.

\section{2. Materials and Methods}

86

87

88

89

90

91

92

93

94

95

96

97

98

99

100

101

\subsection{Study site and experimental setup}

The experiments were carried out aboard the commercial Danish seiner HG 35 Vendelbo (length overall: 15.47 m, engine power: $91 \mathrm{~kW}$ ) off the coast of Denmark in Skagerrak (ICES area IIIa; Fig. 1) in August and September 2014. The fishing took place in sandy shallow areas close to the coast ( 13 m deep, Hauls $1,2,3,6,7)$ that are known to be good grounds for flatfish such as plaice and in deeper grounds ( $68 \mathrm{~m}$ deep, Hauls 4 and 5) that are known to be good for roundfish such as haddock (Melanogrammus aeglefinus).

The vessel's commercial gear was used, which was representative for the Danish seining fleet that operates in Skagerrak and the North Sea. The seine had 380 meshes (nominal mesh size: $120 \mathrm{~mm}$ ) around the fishing circle, and it consisted of a wing section with a weighted $43.6 \mathrm{~m}$ long ground rope, a belly section, and an extension section. The $7 \mathrm{~m}$ long non-tapered codend was made of Nymflex $4 \mathrm{~mm}$ double twine polyethlyene (PE) netting (mesh size: $124.4 \pm 3.0 \mathrm{~mm}, \mathrm{~N}=200$, measured with an OMEGA gauge (Fonteyne et al., 2007)) with 97 open meshes around the circumference. The codend was constructed with one selvedge that included three meshes, following commercial practice. Although scientific selectivity studies are normally carried out with newly produced codends without additional devices (e.g., round straps, protecting bags, or flappers) that could affect selectivity, the codend in this 
102

study was equipped with two round straps (Fig. 2; Herrmann et al., 2006). These two round straps were $1.9 \mathrm{~m}$ in circumference and mounted $0.5 \mathrm{~m}$ ahead of the codline and $2.9 \mathrm{~m}$ in circumference and mounted $1.0 \mathrm{~m}$ ahead of the codline. Round straps are widely used by commercial vessels to limit a codend's circumference just in front of the codline to facilitate fast and more controlled emptying of the codend aboard the vessel, which is thought to improve safety for fishermen handling the gear. However, small variations of the specific mounting of these round straps may occur between vessels. Legal regulations regarding round straps are stated in EU regulation 3440/84. The seine warps used in the current trials were $\sim 2860 \mathrm{~m}$ long (13 coils), each with a diameter of $21 \mathrm{~mm}$.

The covered codend method (Wileman et al., 1996) was applied to catch individuals escaping from the codend. The actual cover was $21 \mathrm{~m}$ long and consisted of two main parts (part C and D, Fig. 2), but two additional pieces of netting (part A and B, Fig. 2) were necessary to attach the cover appropriately to the extension part of the seine. The $11 \mathrm{~m}$ long part $\mathrm{C}$ covered the codend and was made of $0.9 \mathrm{~mm}$ thin knotless Dyneema (ultra-high molecular weight PE) twine netting in square mesh orientation (mesh size: $46.2 \pm 3.0 \mathrm{~mm}$ ) to ensure good water flow through the meshes and a low visibility of the netting in order to not affect the escape behaviour of the fish. Furthermore, this configuration allowed the meshes to stay in a fixed position and thus maintain a sufficient opening and distance between codend and cover in order to minimize the risk of masking the codend (Madsen et al., 2001). This part consisted of four panels and had 620 mesh bars in circumference (155 per panel). The $10 \mathrm{~m}$ long aft part $\mathrm{D}$ was made of $2 \mathrm{~mm}$ knotless PE netting (mesh size: $40.8 \pm 0.7 \mathrm{~mm}$ ) in diamond orientation. It consisted of two panels and the number of meshes per panel decreased from 175 in the front to 145 meshes per panel in the end. Three kites, consisting of two PVC-coated trapezoidal canvas parts (ca. $0.5 \mathrm{~m}^{2}$ per trapezoid) as described by Madsen et al. (2001) were attached to the cover to ensure that it remained open during faster hauling speeds (Figs. 2 and 3). One kite was attached to each of the starboard panel, the portside panel and the top panel (Figs. 2 and 3). Because Danish seines are dragged at a slower speed than trawls, especially in the beginning of the fishing process, several modifications were made to the cover design described in Madsen et al. (2001). These were made to ensure that the cover did not mask the codend 
128 (Madsen and Holst, 2002) at the low dragging speed. Twenty-four egg-shaped floats (buoyancy: $0.2 \mathrm{~kg}$ )

129 were attached along each upper selvedge of the front part, and lead ropes $(1 \mathrm{~kg} / \mathrm{m})$ were attached to the 130 lower panel (Figs. 2 and 3). Additionally, a $1.9 \mathrm{~m}$ long PE bar was fixed transversally across the upper 131 panel at the point where the kites have been attached (Figs. 2 and 3). This ensured the cover to spread 132 horizontally and thus allowed sufficient horizontal space between the codend and cover when the gear 133 was not moving or was moving very slowly. This minimized the risk of masking. Finally, a ca. $10 \mathrm{~m}$ 134 long zipper was inserted in the top panel of part $\mathrm{C}$ to allow handling the codend catch first in order to 135 prevent escapes of fish from the codend into the cover at the surface (Fig. 2). Adjustment and inspection 136 of the cover were conducted in a flume tank (SINTEF, Hirtshals, Denmark) prior to the experiments, 137 with participation of scientists, fishermen, and the net maker who created the cover. Velocities from 0 to $1381.8 \mathrm{kn}(0.9 \mathrm{~m} / \mathrm{s})$, equivalent to the speed of the seine when the majority of fish enter the codend 139 (unpublished data, Thomas Noack, DTU Aqua Hirtshals, Denmark), were tested. As the length of the 140 cover exceeded the flume tank's dimensions, the last part of the cover was bundled for the tests. By doing so, it was still possible to judge and adjust the modifications around the codend (lead ropes, floats, kites, PE bar) in an appropriate way.

\subsection{Data collection and sampling strategy}

For each haul, fishing time, depth at the position where the net was deployed, depth at anchor and the sea state were recorded following the protocol of Wileman et al. (1996). A GPS-logger (Canmore G-PORTER GP-102+) tracked the vessel's movement over the entire fishing process for each haul.

When the catch came aboard the vessel, the codend was emptied first to avoid any fish escaping from the codend into the cover. In order to do so, the cover was tightened up to a level that allowed for 149 a proper opening of the zipper without risking any fish to swim or fall out. As soon as this level was 150 reached, the codend was pulled out of the cover. With the exception of the first haul in which the whole 151 catch was sorted prior to subsampling, subsamples were taken from the non-sorted catch due to large amounts of fish (as outlined by Gerritsen and McGrath (2007)). After sorting and identifying species, 
153

154

155

156

157

158

159

160

161

162

163

164

165

166

167

168

169

170

171 172 by the model.

$173 \mathrm{r}(1, v)=$

174

175

176

177

178 fish were measured to the nearest $\mathrm{cm}$. Individual weights were estimated using length-weight relationships (Shanks, 1981; Coull et al., 1989; Marčeta, 2013).

During the second haul, two underwater video cameras (GoPro, Inc. HERO 3+) were mounted between the cover and codend (pointing downstream and upstream) to document the performance of the cover and the behaviour of the fish in the gear during the fishing process.

\subsection{Data analysis}

Selectivity modelling was conducted to estimate species-specific selectivity curves and selectivity parameters (e.g., L50 and SR) using the computer software SELNET (Herrmann et al., 2012). Hauls with < 10 measured individuals were excluded from further analyses following Krag et al. (2014). The modelling approach followed the procedure described by Sistiaga et al. (2010), Eigaard et al. (2011), Herrmann et al. (2012), and Madsen et al. (2012). In addition to the logistic model (Eq. 1), six other models (Eq. 2-7), including the three other classical size selection models "probit" (Eq. 2), "Gompertz" (Eq. 3) and "Richard" (generalised logistic model with additional asymmetry parameter $1 / \delta$, Eq. 4) were tested within this study. For detailed descriptions of those see Wileman et al. (1996). Additionally, three more complex models that combined two or three logistic models were considered as candidates. Those were the double logistic model "LogitS2" (Eq. 5; Lipovetsky, 2010), the dual selection logistic model "Dual_selection" (Eq. 6; Sistiaga et al., 2010) and the triple logistic model "LogitS3" (Eq. 7; Frandsen et al., 2010a). All models accounted for overdispersion due to haul-pooling. The retention probability $r$ of a fish of length 1 can be expressed by $r(1, v)$ with $v$ describing a vector that contains parameters needed

Logit (1,L50,SR)

Probit (1,L50,SR)

Gompertz (1,L50,SR)

Richard (1,L50,SR, 1/ $)$ 
Dual_selection $\left.=\left(1.0-\mathrm{c}_{1}\right) \times \operatorname{Logit}\left(1, \mathrm{~L} 50_{2}, \mathrm{SR}_{2}\right)+\mathrm{c}_{1} \times \operatorname{Logit}\left(1, \mathrm{~L} 50_{1}, \mathrm{SR}_{1}\right)\right) \times \operatorname{Logit}\left(1, \mathrm{~L}_{0} 0_{2}, \mathrm{SR}_{2}\right)$

$$
\operatorname{LogitS} 3=\mathrm{c}_{1} \times \operatorname{Logit}\left(1, \mathrm{~L} 50_{1}, \mathrm{SR}_{1}\right)+\mathrm{c}_{2} \times \operatorname{Logit}\left(1, \mathrm{~L} 50_{2}, \mathrm{SR}_{2}\right)+\left(1.0-\mathrm{c}_{1}-\mathrm{c}_{2}\right) \times \operatorname{Logit}\left(1, \mathrm{~L}_{50}, \mathrm{SR}_{3}\right)
$$

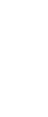

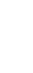

Models that combine two logistic models have been used in previous studies on trawls separating the selectivity process in a towing phase and haul-back phase (Herrmann et al., 2013a). They have also been used in studies on trawls with sorting grids (Kvamme and Isaksen, 2004; Sistiaga et al., 2010; Herrmann et al., 2013b) where the individual fish can escape either through the grid or through the codend meshes. For the double logistic model LogitS2 (Eq. 5) and dual selection model Dual_selection (Eq. 6), the selection process is assumed to consist of two processes. The double logistic model (Eq. 5) combines two logistic models, one for the first process and one for the second process. The contact ratio parameter $\mathrm{c}_{1}$ indicates hereby the probability for an individual to have its selectivity determined by the first process, i.e. the chance of each individual to get in contact with the selective area within the first process (Herrmann et al., 2013a). Consequently, the probability to have its selectivity determined by the second process is $1.0-\mathrm{c}_{1}$. $\mathrm{L}_{50}$ and $\mathrm{SR}_{1}$ or $\mathrm{L}_{5} 0_{2}$ and $\mathrm{SR}_{2}$ describe the selectivity of the according "subprocess". The dual selection model (Eq. 6) is similar to the double logistic model, but it is a sequential function. This means that the proportion of individuals that try to escape in the second process is assumed to consist of those that did not attempt to escape in the first process and additionally those that attempted to, but were retained. The triple logistic model LogitS3 (Eq. 7) follows the same principles as the LogitS2, but includes a third stage of selection, i.e. it is the sum of three logit models in which the weights of the contributions add up to 1.0 (Frandsen et al., 2010a). Additional parameters required by this model to describe selectivity are $\mathrm{L}_{5} \mathrm{O}_{3}$ and $\mathrm{SR}_{3}$ explaining the selection in the third "sub-process" and $\mathrm{c}_{2}$ indicating the probability of an individual to have its selectivity determined by the second process. Consequently, the chance of an individual to have its selectivity determined by the third process is $1.0-$ $\mathrm{c}_{1}-\mathrm{c}_{2}$

Selecting the final model for each species followed the procedure of inspecting goodness of fit as described by Wileman et al. (1996) and by comparing individual Akaike information criterion (AIC) 
values (Akaike, 1974). If the fit statistics indicated a lack of model fit, i.e. p-value close to zero, deviance

206 > degrees of freedom or low $\mathrm{R}^{2}$-value (ratio of variance explained by model and observed variance),

207 residuals were inspected for any structural deviation to determine if structural problems with the model 208 or overdispersion of the data (McCullagh and Nelder, 1989) were causing such results. Uncertainties 209 were estimated by calculating Efron 95\% confidence intervals (CIs; Efron, 1982) for the final selectivity 210 curves and selectivity parameters.

211 Selectivity estimates were compared to values from previous studies of Scottish seines and 212 trawls in the Northeast Atlantic mixed fishery using the estimated selection factor (SF = L50/mesh size).

213 All studies used codends similar to the one used in the present study (mesh orientation: diamond meshes; 214 mesh size: 90-150 mm; twine: 4-6 mm double twine; no grids or release panels), all studies analysed 215 data following guidelines set by Wileman et al. (1996) and all studies were published in peer-reviewed 216 scientific journals. To account for differences in mesh size measurements due to the use of different tools 217 (ICES gauge, EU wedge, OMEGA gauge), values were standardized to EU wedge values (wedge = 218 219 220 0.974*OMEGA + 2.96, derived from Ferro and Xu (1996) and Frandsen et al. (2009); wedge $=1.01$ ICES + 2.96 (Ferro and $\mathrm{Xu}, 1996))$.

All analyses other than the modelling approach were performed using R Statistical Software (R 221 Core Team., 2015).

\section{3. Results}

\section{3.1. Haul and catch overview}

Seven valid hauls were conducted (Table 1), which took between 121 and 140 min from setting 225 out the anchor until the gear was retrieved. Each haul covered an area between 2.58 and $3.04 \mathrm{~km}^{2}$, and 226 depths varied between 7 and $82 \mathrm{~m}$. Catches ranged from 65 to $1503 \mathrm{~kg}$ in the codend and from 327 to $2278415 \mathrm{~kg}$ in the cover. Thirty-one different fish species were caught in this study and the majority of the 
catch was composed of dab (Limanda limanda) and plaice. Other species investigated within this study were cod (Gadus morhua) and red gurnard (Chelidonichthys lucernus).

The inspection of the cover in the flume tank and the underwater recordings from haul 2 indicated that the cover did not mask the codend at any speed within the tests or at any stage of the fishing process in the observed haul. Fish escaping from the codend were not observed to swim back into the codend, although they could easily do so because of the slow towing speed. The observations indicated that the majority of the catch entered the gear relatively late in the catching process. All fish seemed to be in good condition during the whole fishing process and during the handling of the catch on-board.

\subsection{Selectivity estimations and length distributions}

Selectivity curves and parameters were estimated for dab, cod, plaice and red gurnard (Table 2, Table 3). Low numbers of individuals, in combination with relatively high proportions of small fish, resulted in high levels of uncertainty in the analyses. This prohibited an appropriate estimation of selectivity parameters for the other species. A rather high proportion of small fish was also evident for all species where selectivity analyses were possible as the number of individuals in the codend represented only a small part of the total catch (Fig. 4), indicating high numbers of fish escaping into the cover.

A Richard curve with relatively smooth rise (Fig. 4) described the selectivity of cod best (lowest AIC value). The model fit was acceptable ( $\mathrm{p}$-value $=0.81$, deviance $\approx \mathrm{DOF}$ (Degree of freedom), $\mathrm{R}^{2}=$ 0.93; Table 3). Confidence intervals became relatively wide for a range of length classes where the number of observed individuals was low up to length classes with a retention probability of 1.0. The estimated average L50 of $41.6 \mathrm{~cm}$ was higher than the current MLS and had, like the estimated SR (12.6 cm), relatively wide confidence limits (Table 3, Fig. 4).

The selectivity of dab was best described by a triple logistic model (Fig. 4) and the model fit was good (p-value $=0.35$, deviance $\approx \mathrm{DOF}, \mathrm{R}^{2}=1.00$; Table 3 ). Most observed individuals were found in 
253 length classes below the selective area of the gear, but almost all of them were larger than the current 254 MLS of $25 \mathrm{~cm}$ (Fig. 4). The selectivity curve itself was steep with narrow confidence limits. L50 was 255 estimated to be larger than the current MLS of $25 \mathrm{~cm}$ (31.2 on average, Table 3) and SR was found to be narrow $(0.8 \mathrm{~cm}$, Table 3$)$.

A double logistic model best described the selectivity of plaice. Model fit parameters were good (p-value: 0.84 , deviance $\approx \mathrm{DOF}, \mathrm{R}^{2}=1.00$; Table 3). Most individuals belonged to length classes of the lower range of where selectivity took place, but confidence limits of the steep curve were narrow for all length classes. The current MLS of $27 \mathrm{~cm}$ fell within the selective area and laid within the confidence limits for the estimated L50 (average $=29.1 \mathrm{~cm}$, Table 3). SR was estimated to be $2.2 \mathrm{~cm}$ (Table 3).

The selectivity of red gurnard as the only species without MLS (Table 2) could be best described by a logistic model. Since the low p-value (0.00) indicated a potential lack of model fit (Table 3 ), the residuals were investigated. As structures were not detected, it was assumed that overdispersion was at fault and the model could be applied with confidence. The curve had a smooth rise, but was - especially for length classes with retention probabilities above 0.5 - characterized by few observations and wide confidence limits. The estimated L50 and SR values were $31.0 \mathrm{~cm}$ and $11.5 \mathrm{~cm}$, respectively (Table 3).

\section{Discussion}

The goal of this study was to investigate codend selectivity characteristics for several species of fish in a commercial Danish seine as it is currently used in the Danish fishery off the coast of Denmark. An important part of the experimental work was the development of a covered codend methodology that functions at varying towing speeds but particularly at low or no speed. Both flume tank observations and underwater observations indicated that the current approach of combining floats, weights, a distance bar, and kites with a cover made of four panels functioned very well. Thus, this methodology could be applicable in other, similar fisheries where towing speeds are low and variable.

The commercial Danish seine used in this study usually included two rear round straps. Round straps could reduce the mesh opening in a codend and hence the size selectivity by reducing L50, as 
demonstrated by Herrmann et al. (2006) in a simulation study of haddock in trawls. For flatfish, where the morphology of the fish fits a low mesh opening angle, theoretically, the reverse effect could be expected. Because of this, the comparison among trawls, Scottish seines, and Danish seines could be influenced by the round straps, as previous studies used codends without any additional devices. However, effects of other selectivity-influencing factors, such as catch rates, are considered to be stronger than the effects of round straps (Herrmann et al., 2006).

It was possible to estimate selectivity curves for 4 of the 31 caught fish species. The codend mesh size was relatively large, which resulted in low retention for most species. Furthermore, catches of many non-target species were low. For red gurnard, a mismatch between the caught population structure and the selective area of the mesh size was observed, i.e. most observed fish were between $10 \mathrm{~cm}$ and $30 \mathrm{~cm}$, but our model found that full retention was not obtained below $40 \mathrm{~cm}$. For cod, which can grow bigger, the catches were low, especially for larger length classes. This resulted in wide confidence limits of L50 and SR for cod as well as for red gurnard. Therefore, the SF values estimated for cod (3.4), which were on average similar to Scottish seines (3.2), but higher than for trawls (2.4; Table 4), should be used with caution. Future studies should focus on providing stronger selectivity estimates for cod and other species that can grow to sizes that are within the selective area of the gear.

Plaice is the most important species in the Danish seine fishery and, as it is also the case for cod, retention probabilities of small individuals were relatively high. The selectivity curve for plaice indicated a mismatch between the curve and the current MLS, which means that some plaice below MLS were retained. The estimated SF value for Danish seines (2.3) was slightly higher than the mean value of previous trawl studies (2.2), but within their range (2.0 - 2.3; Table 4). This indicates similar amounts of fish below MLS (MCRS) being caught by both gears, which would be discarded today. Although discarded plaice may survive (van Beek et al., 1990), they will have to be brought to land within the landing obligation system and catches will be deducted from the fishermen's quota. However, earnings of these smaller fish are likely low as it will be prohibited to sell fish below MCRS for direct human consumption. The current results would indicate potential consequences of the upcoming landing 
obligation system in terms of catches of smaller plaice to be relatively similar for Danish seiners and trawlers in this area. Uhlmann et al. (2014), however, reported generally lower discard rates for Danish seiners than for trawlers in the Skagerrak/North Sea and other European waters, indicating that in general lower amounts of fish below MLS (MCRS) are caught by the Danish seine fishery. Considering the results of this more general study, the consequences of the change to the landing obligation system are likely to be more pronounced in the trawl fishery. Expectable expenditures are, for instance, the separation of the less valuable catch from the catch with fish above MRCS, the storing of the less valuable part of the catch on board (Sardà et al., 2015) and ultimately the sale of it. As retention probabilities for fish below MLS (MCRS) are similarly high, cod may also become a problematic species within the landing obligation system, but indicated by the smaller average SF value, consequences may again be more pronounced for bottom trawlers. Expenditure in terms of catches of dab and red gurnard are likely

315 to be low as retention probabilities for dab below MLS (MCRS) are very low and red gurnard will still be permitted to be thrown back to sea as it is not part of the list of species that are prohibited to be discarded within the landing obligation.

The selectivity of the two species with the strongest data, dab and plaice, was best described by models indicative of a multiple selection process. Similar models have so far been used when considering the selectivity process in trawling to consist of two or more processes, e.g. when separating the process into towing phase and haul-back phase (Herrmann et al., 2013a) or when using selective devices in addition to the codend (Kvamme and Isaksen, 2004; Sistiaga et al., 2010; Herrmann et al., 2013b).

323 Various factors (e.g., mesh opening or tension in the codend meshes) may, however, affect selectivity 324 characteristics during the fishing process of Danish seining in a similar way and could result in multiple 325 selection processes. For example, increasing hauling speed over time may result in a change of the 326 selectivity characteristics of the codend, as the increasing speed may involve more traction on the gear 327 and on the meshes. The video recordings, however, indicated that most fish entered the seine late during 328 the capture process, thus the number of escapees in the period of slow speeds should be low. Herrmann 329 et al. (2015) suggested that taking the catch from a Scottish seine aboard in several batches leaves fish 

movement. This could cause a constant switch from stiff to slack meshes, which in turn could change selectivity characteristics at the surface and between the underwater and surface parts of the fishing process. However, catches in the current study were small enough to lift on board at once in most cases. Slack meshes may also occur when the seine ropes are retrieved and the seine needs to be stopped in order to be detached from the ropes and attached to the net drum for final retrieval. In contrast to a trawler, a Danish seiner is anchored at this time, and this stop leads to a complete standstill of the gear. Slack meshes in combination with lively fish that are in the seine for only a short period compared to fish in a trawl may explain the observed multiple selection in the Danish seine fishery. Therefore, more complex models that include dual or multiple models should be considered when describing selectivity of a Danish seine. Such approaches may result in different selectivity curves or different selectivity

341 parameter estimates compared to those generated by the more traditional logistic models (Herrmann et 342 al., 2016).

The selectivity estimates generated in this study provide some initial information about several 344 fish species for which selectivity data have not been collected previously for Danish seines (all species) or any other fishing gears (dab, red gurnard). This information is important for assessing the ecosystem

346 effects of fishing gears, for reference when issuing certificates for sustainable fisheries, and for

347 evaluating the EU landing obligation system which requires the entire catch of listed species to be 348 counted against a quota. To gain more knowledge about species that were observed in too few amounts 349 within this study, more experiments need to be conducted, whereby it may be necessary to use non350 commercial codends with smaller mesh sizes to retain more individuals in the codend.

\section{Acknowledgement}

The authors thank the crew of the HG 35 Vendelbo and net maker Ray Godtliebsen as well as

353 Gert Holst, Reinhardt Jensen, and other technicians from DTU Aqua for being indispensable in 354 preparing, conducting, and completing follow-up work for the sea trials. This study was conducted as 
Fisheries.

\section{References}

Akaike, H., 1974. A new look at the statistical model identification. IEEE Trans. on Auto. Control 19, 716-723. http://dx.doi.org/10.1109/TAC.1974.1100705

Condie, H.M., Grant, A., Catchpole, T.L., 2014a. Incentivising selective fishing under a policy to ban discards; lessons from European and global fisheries. Mar. Pol. 45, 287-292. http://dx.doi.org/10.1016/j.marpol.2013.09.001

Condie, H.M., Catchpole, T.L., Grant, A., 2014b. The short-term impacts of implementing catch quotas and a discard ban on English North Sea otter trawlers. ICES J. Mar. Sci. 71, 12661276. http://dx.doi.org/10.1093/icesjms/fst187

Coull, K.A., Jermyn, A.S., Newton, A.W., Henderson, G.I., Hall, W.B., 1989. Length/Weight Relationships for 88 species of Fish Encountered in the North East Atlantic. Scottish Fisheries Research Report 43. $81 \mathrm{pp}$.

EEC, 2011. Proposal of 13 July 2011 for a regulation of the European Parliament and of the Council on the Common Fisheries Policy No 2011/0195. Office for Official Publications of the EEC, Brussels. 11.

EEC, 2012. Proposal of 29 August 2012 for a regulation of the European parliament and of the council on certain technical and control measures in the Skagerrak and amending Regulation, (EC) No 850/98 and Regulation (EC) No 1342/2008. Office for Official Publications of the EEC, Brussels. 18.

Efron, B., 1982. The jackknife, the bootstrap, and other resampling plans. Society for Industrial and Applied Mathematics, Philadelphia. 96 pp pp. http://dx.doi.org/10.1137/1.9781611970319

Eigaard, O.R., Herrmann, B., Rasmus Nielsen, J., 2011. Influence of grid orientation and time of day on grid sorting in a small-meshed trawl fishery for Norway pout (Trisopterus esmarkii). Aquat. Liv. Res. 25, 15-26. http://dx.doi.org/10.1051/alr/2011152

Eigaard, O.R., Bastardie, F., Breen, M., Dinesen, G.E., Hintzen, N.T., Laffargue, P., Mortensen, L.O., Nielsen, J.R., Nilsson, H.C., O’Neill, F.G., Polet, H., Reid, D.G., Sala, A., Sköld, M., Smith, C., Sørensen, T.K., Tully, O., Zengin, M., Rijnsdorp, A.D., 2015. Estimating seabed pressure from demersal trawls, seines, and dredges based on gear design and dimensions. ICES J. Mar. Sci. http://dx.doi.org/10.1093/icesjms/fsv099

Eliasen, S.Q., 2014. Cod avoidance by area regulations in Kattegat - experiences for the implementation of a discard ban in the EU. Mar. Pol. 45, 108-113. http://dx.doi.org/10.1016/j.marpol.2013.11.020

EuroStat, 2016. Fishing fleet by type of gear and engine power. http://appsso.eurostat.ec.europa.eu/nui/show.do?dataset=fish fleet gp\&lang=en (last accessed 04 July 2016).

Ferro, R.S.T., Xu, L., 1996. An investigation of three methods of mesh size measurement. Fish. Res. 25, 171-190. http://dx.doi.org/10.1016/0165-7836(95)00403-3

Fonteyne, R., Buglioni, G., Leonori, I., O’Neill, F.G., Fryer, R.J., 2007. Laboratory and field trials of OMEGA, a new objective mesh gauge. Fish. Res. 85, 197-201. http://dx.doi.org/10.1016/j.fishres.2007.02.006

Frandsen, R.P., Holst, R., Madsen, N., 2009. Evaluation of three levels of selective devices relevant to management of the Danish Kattegat-Skagerrak Nephrops fishery. Fish. Res. 97, 243-252. http://dx.doi.org/10.1016/j.fishres.2009.02.010 
Frandsen, R.P., Herrmann, B., Madsen, N., 2010a. A simulation-based attempt to quantify the morphological component of size selection of Nephrops norvegicus in trawl codends. Fish. Res. 101, 156-167. http://dx.doi.org/http://dx.doi.org/10.1016/j.fishres.2009.09.017

Frandsen, R.P., Madsen, N., Krag, L.A., 2010b. Selectivity and escapement behaviour of five commercial fishery species in standard square- and diamond-mesh codends. ICES J. Mar. Sci. 67, 1721-1731. http://dx.doi.org/10.1093/icesjms/fsq050

Gerritsen, H.D., McGrath, D., 2007. Precision estimates and suggested sample sizes for lengthfrequency data. Fish. Bull. 105, 116-120.

Graham, N., O’Neill, F.G., Fryer, R.J., Galbraith, R.D., Myklebust, A., 2004. Selectivity of a 120mm diamond cod-end and the effect of inserting a rigid grid or a square mesh panel. Fish. Res. 67, 151-161. http://dx.doi.org/10.1016/j.fishres.2003.09.037

Herrmann, B., Priour, D., Krag, L.A., 2006. Theoretical study of the effect of round straps on the selectivity in a diamond mesh cod-end. Fish. Res. 80, 148-157. http://dx.doi.org/10.1016/j.fishres.2006.04.018

Herrmann, B., Sistiaga, M., Nielsen, K.N., Larsen, R.B., 2012. Understanding the size selectivity of redfish (Sebastes spp.) in North Atlantic trawl codends. J. Northw. Atl. Fish. Sci. 44, 1-13. http://dx.doi.org/10.2960/J.v44.m680

Herrmann, B., Mieske, B., Stepputtis, D., Krag, L.A., Madsen, N., Noack, T., 2013a. Modelling towing and haul-back escape patterns during the fishing process: a case study for cod, plaice, and flounder in the demersal Baltic Sea cod fishery. ICES J. Mar. Sci. 70, 850-863. http://dx.doi.org/10.1093/icesjms/fst032

Herrmann, B., Sistiaga, M., Larsen, R.B., Nielsen, K.N., Grimaldo, E., 2013b. Understanding sorting grid and codend size selectivity of Greenland halibut (Reinhardtius hippoglossoides). Fish. Res. 146, 59-73. http://dx.doi.org/http://dx.doi.org/10.1016/j.fishres.2013.04.004

Herrmann, B., Larsen, R.B., Sistiaga, M., Madsen, N.A.H., Aarsæther, K.G., Grimaldo, E., Ingolfsson, O.A., 2015. Predicting size selection of cod (Gadus morhua) in square mesh codends for demersal seining: A simulation-based approach. Fish. Res. http://dx.doi.org/10.1016/j.fishres.2015.07.015

Herrmann, B., Krag, L.A., Feekings, J., Noack, T., 2016. Understanding and Predicting Size Selection in Diamond-Mesh Cod Ends for Danish Seining: A Study Based on Sea Trials and Computer Simulations. Marine and Coastal Fisheries 8, 277-291. http://dx.doi.org/10.1080/19425120.2016.1161682

ICES, 2006. Report of the Working Group on Ecosystem Effects of Fishing Activities (WGECO), 512 April 2006, ICES Headquarters, Copenhagen. ACE:05. 174 pp.

ICES, 2010. Report of the ICES - FAO Working Group on Fishing Technology \& Fish Behaviour (WGFTFB). ICES CM 2010/SSGESST:14. 252 pp.

ICES, 2015. Report of the Working Group on the Assessment of Demersal Stocks in the North Sea and Skagerrak (WGNSSK), 28 April-7 May, ICES HQ, Copenhagen, Denmark. ICES CM 2015/ACOM:13. 1031.

Isaksen, B., Lokkeborg, S., 1993. Escape of cod (Gadus morhua) and haddock (Melanogrammus aeglefinus) from Danish seine codends during fishing and surface hauling operations. ICES Mar. Sci. Symp. 196, 86-91.

Krag, L.A., Herrmann, B., Karlsen, J.D., 2014. Inferring Fish Escape Behaviour in Trawls Based on Catch Comparison Data: Model Development and Evaluation Based on Data from Skagerrak, Denmark. PLoS One 9, e88819. http://dx.doi.org/10.1371/journal.pone.0088819

Kvamme, C., Isaksen, B., 2004. Total selectivity of a commercial cod trawl with and without a grid mounted: grid and codend selectivity of north-east Artic cod. Fish. Res. 68, 305-318. http://dx.doi.org/http://dx.doi.org/10.1016/j.fishres.2003.11.011

Lipovetsky, S., 2010. Double logistic curve in regression modeling. J. Appl. Stat. 37, 1785-1793. http://dx.doi.org/10.1080/02664760903093633

Madsen, N., Hansen, K.E., Moth-Poulsen, T., 2001. The kite cover : a new concept for covered codend selectivity studies. Fish. Res. 49, 219-226. http://dx.doi.org/10.1016/S0165-7836(00)00210-1 
Madsen, N., Holst, R., 2002. Assessment of the cover effect in trawl codend selectivity experiments. Fish. Res. 56, 289-301. http://dx.doi.org/10.1016/S0165-7836(01)00330-7

Madsen, N., Herrmann, B., Frandsen, R.P., Krag, L.A., 2012. Comparing selectivity of a standard and turned mesh T90 codend during towing and haul-back. Aquat. Liv. Res. 25, 231-240. http://dx.doi.org/10.1051/alr/2012021

Marčeta, B.,2013. Length-weight relationship of Arnoglossus laterna from the Gulf of Trieste, sampled from 2.2.2000 to 19.3.2013 $(\mathrm{n}=116$, length range from $7.2 \mathrm{~cm}$ to $16.0 \mathrm{~cm})$. www.biosweb.org/openpdf.php?ctivo=6029.pdf. (accessed: 08-07-2015).

McCullagh, P., Nelder, J.A., 1989. Generalized Linear Models, Second Edition. Chapman and Hall, London. $511 \mathrm{pp}$ pp.

R Core Team., 2015. R: A Language and Environment for Statistical Computing. R Foundation for Statistical Computing. Vienna. Available at: https://www.R-project.org/ ( accessed 15 December 2015).

Reeves, S.A., Armstrong, D.W., Fryer, R.J., Coull, K.A., 1992. The effects of mesh size, cod-end extension length and cod-end diameter on the selectivity of Scottish trawls and seines. ICES J. Mar. Sci. 49, 279-288. http://dx.doi.org/10.1093/icesjms/49.3.279

Sardà, F., Coll, M., Heymans, J.J., Stergiou, K.I., 2015. Overlooked impacts and challenges of the new European discard ban. Fish Fish. 16, 175-180. http://dx.doi.org/10.1111/faf.12060

Shanks, A.M., 1981. Further analysis of total weight/length data for spur dogfish. DAFS Marine Laboratory lnternal Report.

Sistiaga, M., Herrmann, B., Grimaldo, E., Larsen, R.B., 2010. Assessment of dual selection in grid based selectivity systems. Fish. Res. 105, 187-199. http://dx.doi.org/10.1016/j.fishres.2010.05.006

Suuronen, P., Chopin, F., Glass, C., Løkkeborg, S., Matsushita, Y., Queirolo, D., Rihan, D., 2012. Low impact and fuel efficient fishing - Looking beyond the horizon. Fish. Res. 119-120, 135-146. http://dx.doi.org/10.1016/j.fishres.2011.12.009

Thrane, M., 2004. Energy Consumption in the Danish Fishery: Identification of Key Factors. J. Ind. Ecol. 8, 223-239. http://dx.doi.org/10.1162/1088198041269427

Uhlmann, S.S., van Helmond, A.T.M., Kemp Stefánsdóttir, E., Sigurðardóttir, S., Haralabous, J., Bellido, J.M., Carbonell, A., Catchpole, T., Damalas, D., Fauconnet, L., Feekings, J., Garcia, T., Madsen, N., Mallold, S., Margeirsson, S., Palialexis, A., Readdy, L., Valeiras, J., Vassilopoulou, V., Rochet, M.-J., 2014. Discarded fish in European waters: general patterns and contrasts. ICES J. Mar. Sci. 71, 1235-1245. http://dx.doi.org/10.1093/icesjms/fst030

van Beek, F.A., van Leeuwen, P.I., Rijnsdorp, A.D., 1990. On the survival of plaice and sole discards in the otter-trawl and beam-trawl fisheries in the North Sea. Netherlands Journal of Sea Research 26, 151-160. http://dx.doi.org/http://dx.doi.org/10.1016/0077-7579(90)90064-N

von Brandt, A., 2005. Fish Catching Methods of the World. Blackwell publishing, Oxford. 523 pp. 275-290 pp.

Wileman, D.A., Ferro, R.S.T., Fonteyne, R., Millar, R.B., 1996. Manual of Methods of Measuring the Selectivity of Towed Fishing Gears. ICES Coop. Res. Rep., No. 215. 216 pp. 
494 Figure 1. Area and vessel tracks for the seven hauls conducted for the codend selectivity trials aboard 495 the HG 35 Vendelbo in 2014.

496 Figure 2. Schematic drawing of the codend cover and its attachment to the seine including information 497 about modifications to account for different stages of the fishing process (kites, floats, lead ropes, PE 498 bar). Information about netting and number of panels/selvedges in the specific parts is also included 499 (cross sections in top of drawing). A and B are necessary parts to attach the cover to the seine net. C 500 represents part of the cover around the area of the codend where the main selection is expected to take 501 place and D serves for storing the fish in the cover. 1: Kites. 2: $1.9 \mathrm{~m}$ PE bar (transversal). 3: Floats. 4: 502 Zipper. 5: $3 \mathrm{~m}$ long lead rope. 6: $1.7 \mathrm{~m}$ long lead rope (transversal). 7: $2.1 \mathrm{~m}$ long lead rope.

503 Figure 3. Preliminary assessment of the cover with wrapped rear part in flume tank. For clarification of 504 parts of cover and items attached to it see Fig. 2 and section 2.1.

505 Figure 4. Selectivity curves for fish including 95\% confidence intervals (grey shaded areas), length506 specific retention rates (white diamonds), current species-specific MLS if available (vertical stippled 507 line), and length distributions (stippled line: total; solid line: codend). Numbers in parentheses indicate 508 number of hauls used for analysis (i.e. those that had $>10$ measured individuals). 
511 Figure 1:

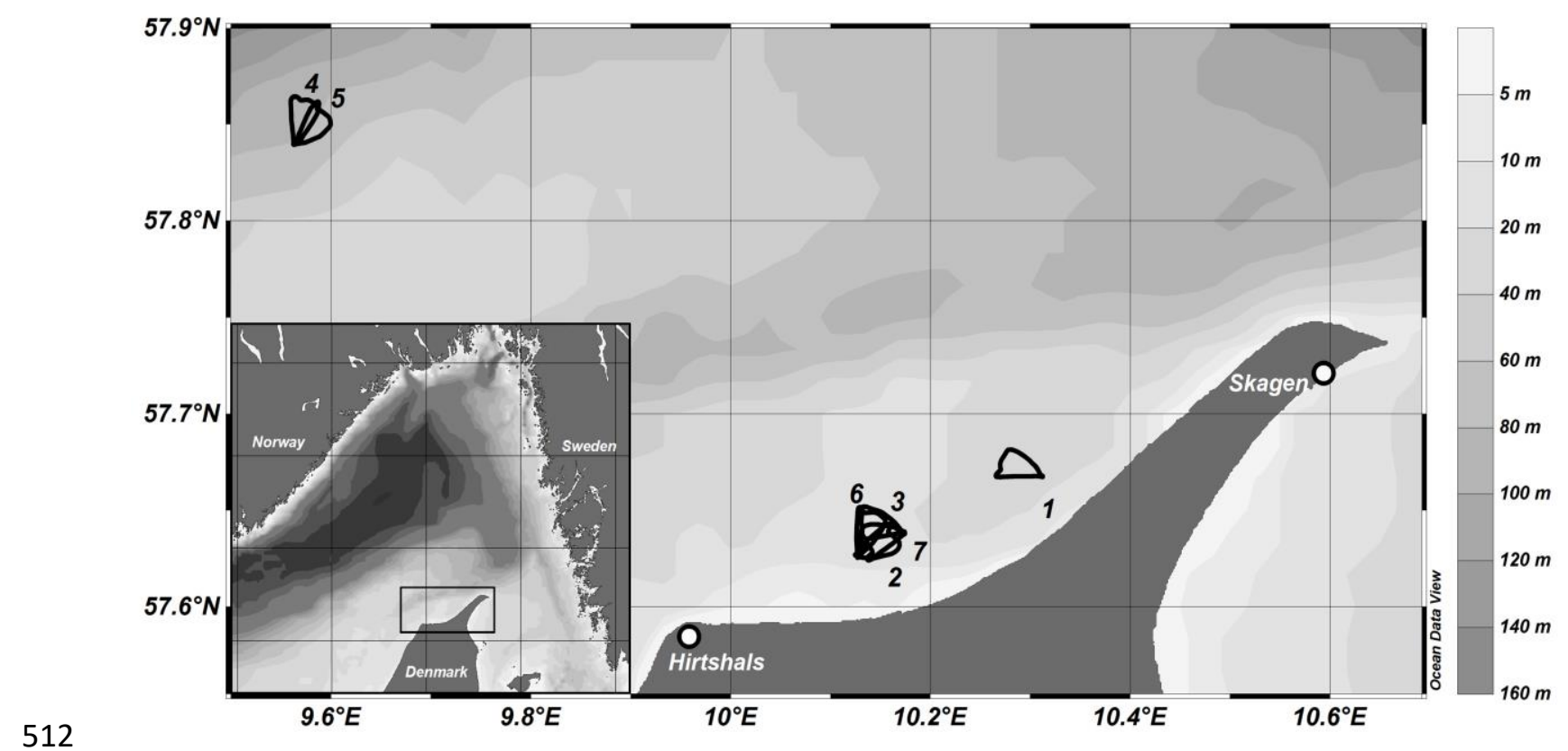

Page 19 
513 Figure 2:
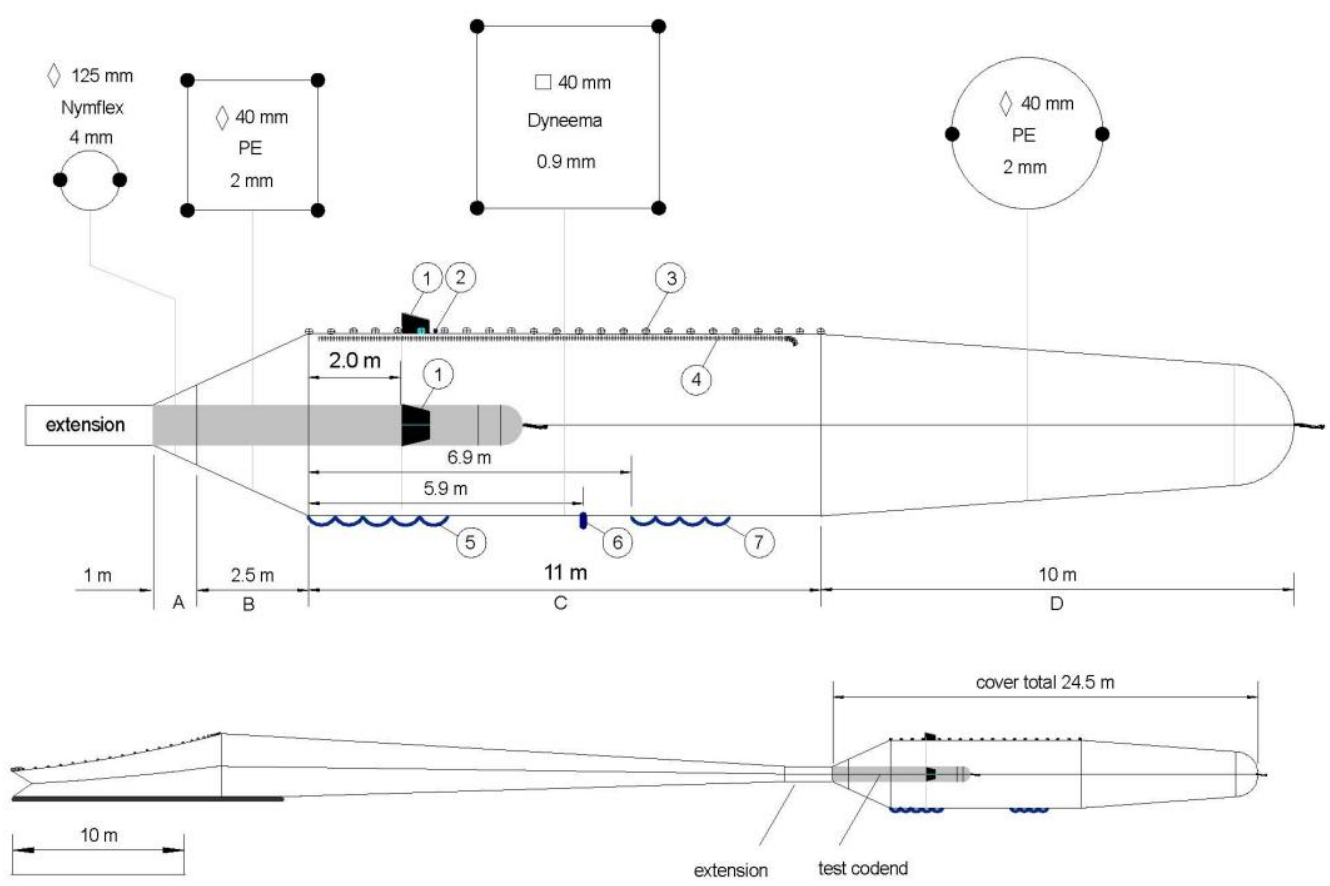

514

515

Page 20 
516 Figure 3:

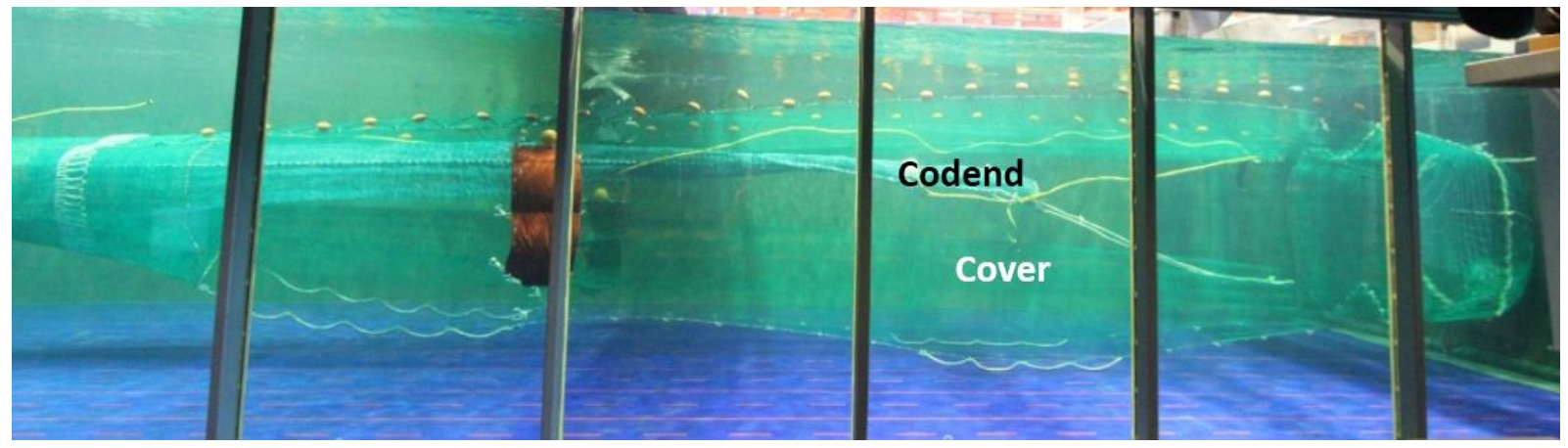

518

Page 21 
Figure 4:

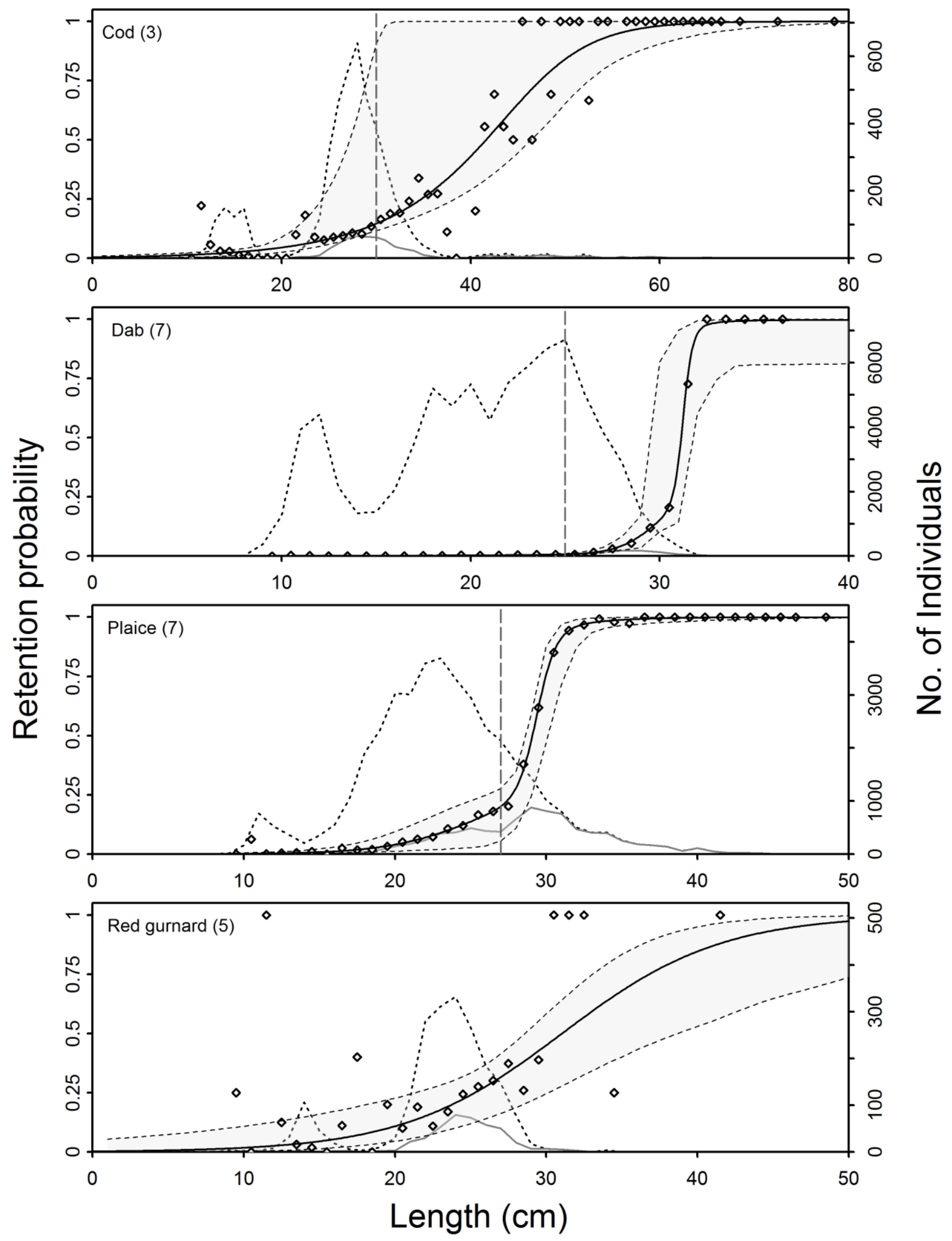

Page 22 
1 Table 1. Overview of hauls conducted for the codend selectivity trials aboard the HG 35 Vendelbo in

2 2014, including information about time, haul conditions, and total catches. Duration describes time from

3 setting anchor until gear was retrieved aboard the vessel. Depth is for the position where the anchor was

$4 \quad$ set and where the seine was deployed. Sea states as described by Wileman et al. (1996).

\begin{tabular}{|c|c|c|c|c|c|c|c|c|}
\hline \multirow{2}{*}{ Haul } & \multirow{2}{*}{ Date } & \multirow{2}{*}{$\begin{array}{l}\text { Duration } \\
\text { (min) }\end{array}$} & \multirow{2}{*}{$\begin{array}{l}\text { Covered area } \\
\qquad\left(\mathrm{km}^{2}\right)\end{array}$} & \multicolumn{2}{|c|}{ Depth (m) } & \multirow{2}{*}{ Sea state } & \multicolumn{2}{|c|}{ Total Catch $(\mathrm{kg})$} \\
\hline & & & & Anchor & Seine & & Codend & Cover \\
\hline 1 & 29.08 .2014 & 136 & 2.69 & 25.6 & 18.3 & 1 & 1503 & 8415 \\
\hline 2 & 01.09 .2014 & 136 & 2.85 & 12.8 & 9.1 & 2 & 198 & 1328 \\
\hline 3 & 01.09 .2014 & 137 & 3.04 & 12.8 & 12.8 & 2 & 207 & 1275 \\
\hline 4 & 02.09 .2014 & 122 & 2.83 & 65.8 & 82.3 & 2 & 512 & 1174 \\
\hline 5 & 02.09 .2014 & 121 & 2.58 & 65.8 & 56.7 & 2 & 470 & 1068 \\
\hline 6 & 03.09 .2014 & 140 & 2.93 & 7.3 & 11.0 & 2 & 65 & 327 \\
\hline 7 & 03.09 .2014 & 135 & 2.82 & 7.3 & 12.8 & 1 & 69 & 1023 \\
\hline
\end{tabular}

6 Table 2. Analysed catch data including information about length range, number of measured

7 individuals, and sampling ratio. Current MLS (minimum landing size; if available) is given in

8 parentheses. * indicates species that will have a minimum reference conservation size in the future. NA

9 indicates that there is no MLS present for this species.

\begin{tabular}{|c|c|c|c|c|c|}
\hline \multirow{2}{*}{ Species } & \multirow{2}{*}{$\begin{array}{l}\text { Length range } \\
\qquad(\mathrm{cm})\end{array}$} & \multicolumn{2}{|c|}{ Codend } & \multicolumn{2}{|c|}{ Cover } \\
\hline & & No. measured & Sampling ratio & No. measured & Sampling ratio \\
\hline Cod $(30 \mathrm{~cm})^{*}$ & $10-78$ & 620 & 1 & 1070 & 0.272 \\
\hline $\operatorname{Dab}(25 \mathrm{~cm})$ & $9-36$ & 1053 & 1 & 4903 & 0.063 \\
\hline Plaice $(27 \mathrm{~cm})^{*}$ & $9-51$ & 2937 & 0.353 & 3404 & 0.109 \\
\hline Red gurnard (NA) & $9-41$ & 427 & 1 & 458 & 0.287 \\
\hline
\end{tabular}

10

11 Table 3. Summary of model parameters selectivity parameters (L50 as length with 50\% retention, SR as 12 selection range) with $95 \%$ confidence limits, name of model used, and values describing goodness of fit 13 (DOF $=$ degree of freedom). See sections 2.3 and 3.2 for explanations of selectivity parameters and model 14 fit values.

\begin{tabular}{ccccc}
\hline Parameters & Cod & Dab & Plaice & Red gurnard \\
\hline L50 & $41.6(27.2-46.4)$ & $31.2(29.6-31.6)$ & $29.1(28.7-30.1)$ & $31.0(28.6-38.7)$ \\
SR & $12.6(4.8-16.0)$ & $0.8(0.1-2.7)$ & $2.2(1.7-3.6)$ & $11.5(7.9-26.6)$ \\
$1 / \delta$ & $0.5(0.1-1.3)$ & - & - & - \\
$\mathrm{L}_{1}$ & - & $31.3(30.4-148.6)$ & $29.4(29.1-30.5)$ & - \\
$\mathrm{SR}_{1}$ & - & $0.5(0.1-59.5)$ & $1.4(1.0-10.4)$ & - \\
$\mathrm{L}_{2}$ & - & $29.8(16.1-31.3)$ & $25.5(20.0-29.7)$ & - \\
$\mathrm{SR}_{2}$ & - & $2.2(0.1-20.3)$ & $6.5(1.6-11.0)$ & - \\
$\mathrm{L}_{3}$ & - & $28.0(0.1-30.0)$ & - & - \\
$\mathrm{SR}_{3}$ & - & $15.1(0.1-100.0)$ & - & - \\
Contact ratio 1 & - & $0.7(0-1.0)$ & $0.7(0.1-0.9)$ & -
\end{tabular}

Page 1 


\begin{tabular}{ccccc} 
Contact ratio 2 & - & $0.2(0-1.0)$ & - & - \\
Model & Richard & LogitS3 & LogitS2 & Logit \\
P-value & 0.8101 & 0.3499 & 0.8423 & 0.0000 \\
Deviance & 45.70 & 21.92 & 26.69 & 71.67 \\
DOF & 55 & 20 & 35 & 24 \\
$\mathrm{R}^{2}$-value & 0.93 & 1.00 & 1.00 & 0.33 \\
\hline
\end{tabular}

15

16 Table 4. Comparison of estimated selection factors (SFs) between this study and previous selectivity

17 studies of Scottish seines and trawls. Data values are mean and range.

\begin{tabular}{ccrr}
\hline \multirow{2}{*}{ Species } & $\begin{array}{c}\text { SF - present study } \\
\text { Danish seine }\end{array}$ & \multicolumn{2}{c}{ SF - former studies } \\
\cline { 3 - 4 } & 3.4 & Scottish seine & Trawl \\
\hline Cod & & $3.2(2.0-3.8)$ & $2.4(1.6-3.4)$ \\
& 2.3 & 1,2 & $1,3,4,5,6,7,8$ \\
Plaice & & - & $2.2(2.0-2.3)$ \\
& & & $5,6,7,8$ \\
\hline
\end{tabular}

18 Reeves et al., 1992; ${ }^{2}$ Isaksen and Løkkeborg, 1993; ${ }^{3}$ Graham et al., 2004; ${ }^{4}$ Madsen and Stæhr, 2005; ${ }^{5}$ Frandsen et al., 2009;

$19{ }^{6}$ Frandsen et al., 2010; ${ }^{7}$ Frandsen et al., 2011; ${ }^{8}$ Madsen et al., 2012 